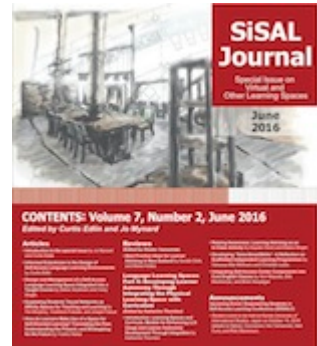

ISSN 2185-3762

Studies in Self-Access Learning Journal

http://sisaljournal.org

\title{
Best Practice Ideas for Learner Advising in New Zealand
}

Moira Hobbs, Unitec Institute of Technology, New Zealand

Kerstin Dofs, Ara Institute of Canterbury, New Zealand

Corresponding authors: mhobbs@unitec.ac.nz /

Kerstin.Dofs@ara.ac.nz

Publication date: June, 2016.

\section{To cite this article}

Hobbs, M., \& Dofs, K. (2016). Best practice ideas for learner advising in New Zealand. Studies in Self-Access Learning Journal, 7(2), 182-192.

\section{To link to this article}

http://sisaljournal.org/archives/jun16/hobbs_dofs

This article may be used for research, teaching and private study purposes. Please contact the authors for permission to re-print elsewhere.

Scroll down for article 


\section{Best Practice Ideas for Learner Advising in New Zealand}

Moira Hobbs, Unitec Institute of Technology, New Zealand

Kerstin Dofs, Ara Institute of Canterbury, New Zealand

In this article, the authors will present a short discussion about the role of self-access and advising in language education, after which they will describe workshops they conducted, and disseminate ideas for best practice for advising that were shared by participants at two conferences in New Zealand.

Higher educational institutions in New Zealand today are committed to providing optimal academic development and support to both international and domestic students. Two of the most important outcomes of these interventions are to maintain the success and retention rates at the highest level possible. This is in the best interest of the students and also of all tertiary institutions in New Zealand today, as they have to fulfil the Government goals of improved service with funding being performance-linked, and indeed "The Government is starting to see encouraging results from its focus on improving the performance and value for money of tertiary education" (Ministry of Education, 2014, p. 5).

Since the early 90's there have been a growing number of pivotal publications about autonomous learning/independent learning/self-access centres (SACs) (Benson 2011; Benson \& Voller, 1997; Crabbe, 1993; Dickinson \& Wenden, 1995; Gardner \& Miller, 1994; 1996; Miller \& Rogerson-Revell, 1993; Pemberton, Li, Or, \& Pierson, 1996; Sheerin, 1991; 1993). Following an investigation and overview of SACs at Australian and New Zealand tertiary institutions (Anderson \& Jones-Parry, 2003; Reinders, Reinders, \& Lazaro, 2007), more recent research has focused on the associated student advisory services from both students' (Hobbs \& Jones-Parry, 2007) and advisors' standpoints (Dofs \& Hobbs, 2011). Other publications discuss establishing ILCs (Gardner \& Miller, 1999; Dofs, \& Hobbs, 2011), the former giving an international overview and the latter with a New Zealand perspective. What is apparent is that ILC's are here to stay and are increasingly being built on sound theoretical underpinning rather than simply practical factors. Indeed, Ara Institute of Canterbury are currently redeveloping this facility.

As shown in the above studies, many tertiary institutions in New Zealand aspire to provide some form of useful and beneficial Independent Learning Centre (ILC) in order to 
encourage life-long learning, and support students towards taking more control of their learning processes. ILCs (sometimes called SACs or ELSACs) are places where learners are encouraged to develop their skills and autonomy. Such centres are increasingly offering student advisory services that hone such skills in the students. These centres are popular with students as they provide a safe, affirming and comfortable place to make progress in learning. The popularity travels far by word of mouth and the state of the art facilities bring a point of difference to an institution. However the nature of these centres may be changing as institutional libraries increase their stocks of suitable materials and provide increasing learner-friendly spaces.

The process of setting up, developing and maintaining such centres has been researched and outlined in Dofs \& Hobbs (2011). They found that the goal of fostering autonomous learners at New Zealand institutions is being met in varying ways, using a range of strategies, by different departments and schools within the same institution, from developing and expanding existing centres to providing encouragement for establishing new ones.

There are several advantages in maintaining ILCs, such as:

- They can aid enhancement and development of learner capability for successful further academic studies

- They may attract domestic and international students who want a facility dedicated to autonomous learning

- They are an effective marketing tool for institutions

- They facilitate development of life-long learning skills

There is also a need to optimise targeted support and encouragement for learners so they can become more able to study autonomously and/or on their own, and to teach learners the skills and strategies to do this. Thus what is of the greatest importance is that, if independent learning facilities are to be offered, then an advisory service to match must be developed. According to Cooker \& Torpey (2004) when describing the then-new Self-Access Learning Centre at Kanda University of University Studies:

the availability of this state-of-the-art centre does not automatically ensure learner independence. Thus we strive to offer more than just a facility. Our most valuable resource is in fact our learning advisors who work closely with the learners to provide advice on developing learning 
strategies, finding ways to use the equipment in the centre, locating appropriate materials, and understanding particularly difficult aspects of language. (p. 3).

As a number of authorities in the field rightly point out, just providing these resources does not necessarily foster autonomous learners. Benson (2001) states that "the research evidence suggests that the opportunity to direct one's learning, does not in itself lead to greater autonomy or better language learning" (p. 134). He suggests that it is likely that resource based learning pre-supposes that the learner already possesses some of the skills associated with autonomy. One of the ways to address this is by providing clear pathways into self-access studies. As Jones-Parry and \& Vinkenvleugel found:

Another equally important and associated way is to provide scaffolding stages to help the learner along. We also have to be careful that we do not expose the learner to a totally individualistic experience. After all, much of the work done in many self-access centres is of a solitary nature. So authentic communication is extremely important and opportunities for learners to engage in small group work within the centre would go some way to providing opportunities for the cooperative decision making that some researchers see as vital to the development of autonomy (Presentation at CLESOL Conference, July, 2002).

Poulshock (2010) states that educators of humanities and science subjects aim to help students develop the following skills and knowledge:

- Critical thinking

- Analytical reading

- Multiple problem solving

- Learning how experts think and learn

- Developing social and global knowledge

- Gaining self-knowledge and moral values

- Integrating knowledge across disciplines

These are key aspects that often arise during learning advisor and student consultations. Mynard \& Carson (2012) take this a step further when they describe advising 
as involving "the process and practice of helping students to direct their own paths so as to become more effective and more autonomous..." (p. 4). Thus the development of advisory services within the context of an ILC is congruent with the broader aims of an institution in developing its students whatever their chosen discipline.

An ILC is, as suggested above, a melding of many skills, requirements and pathways in which meeting students' educational needs is a major focus. As stated by Dofs (2007), teacher and student voices in mature centres have made themselves clear that there is a need for:

- Practical links to the classroom

- Manifold pathways to learning within the centre

- Advice on how to learn

- Learning how to set goals

- Learning how to evaluate learning

All of these requests can be met by an efficient, pedagogically sound research-based student advisory service. This is the rationale behind student advisory service being a vital offering to students in New Zealand. The journey towards one such advisory service is documented in Vinkenvleugel, Lotovale and Jones-Parry (2004). Advisors with a vast experience of guiding students can highlight any potential difficulties and clarify the issues, on the spot, allowing students to exploit their problem-solving skills. Thus, an effective service introduces learners to alternative learning paths, including the necessary awareness of how to learn best, set goals, measure achievements, as well as conduct self-evaluations. Mozzon-McPherson (2001) believes that learner advising plays a key role in developing independence: "a SAC, having an aim to gradually develop autonomous learners, generates a need for staff in an advising role to supplement the role of the teacher" (p. 5). In some New Zealand ILCs teachers are also advisors for their classes whereas other centres employ dedicated advisors or facilitators.

Being also informed by research by the authors (Dofs \& Hobbs, 2011; Hobbs \& Dofs 2015), the authors conducted workshops at two recent conferences, one hosted by the Association of Tertiary Learning Advisors Aotearoa New Zealand (ATLAANZ) and the other by Community Languages and English for Speakers of Other Languages (CLESOL). The aims of these workshops were to find out and outline some good practice guidelines for addressing the support needed to enable students to become more autonomous lifelong learners. More evidence of the need for professional development has become apparent in 
recent times. Adequate training and qualification pathways for advisors which include the concept of autonomous learning seem not to be available in New Zealand. The authors have each received invitations from external universities and polytechnics to facilitate professional development for teachers who are moving into an autonomous learning advisory role as part of their teaching. There has also been an increased interest recently in purchasing Ara's Autonomous Language Learning Guides, (Dofs, unpublished Master of Language Learning and Technology dissertation, 2011) as a means of establishing learner support at institutions in New Zealand as well as overseas.

The summary below shows suggestions and comments about good advising practice in New Zealand, put forward by conference workshop delegates at two recent conferences. The first one was organised by and for academic advisors, the ATLAANZ Conference, from 27-29 November 2013. The other one was languages based; the CLESOL Conference, from 10-13 July 2014. At both conferences, participants were asked to form small groups to discuss and note down ideas about what they thought was most important for students' success. The following list reflects a summary of these views held by many advisors in New Zealand today. These were mainly educators involved in academic learning development and general learning support, but also some language teachers with a special interest in learning, support, independence, autonomy, and advising (or counselling) students to reach their own goals and capacities. This compilation also includes suggestions about how to enable autonomous learning.

\section{Views of Academic Advisors about Appropriate Student Knowledge and Training}

- In order to develop autonomous learning and succeed with their assignments, students need to have access to appropriate information and study guides, which may include a range of specific activities which they can undertake, to improve success with their assignments.

- $\quad$ Students may also require help to develop skills to find useful resources.

- $\quad$ Other 'learning to learn' aspects for autonomous learning mentioned by the Advisors which students can generally benefit from are:

- planning skills (which may include time management, knowledge transfer, and reasoning skills)

- reflecting regularly on their own learning 
- knowing how to engage with their studies, which may enhance and empower their learning of specific knowledge and skills for accomplishing assignments - understanding the differences between independence versus dependence (including the idea of interdependence, when students may rely on each other for learning, e.g. through study groups)

- It is important to develop critical thinking skills using questioning techniques and brainstorming so that students can question and discuss topics of interest and thereby develop independent thoughts

- It was especially noted that advisors should show students how to reflect on learning and thereby encourage self-reflection.

- $\quad$ For all of the above to be able to take place, advisors need to have a deep knowledge about beneficial study strategies and resources, both in-house and elsewhere, such as those easily accessible on Internet websites and through learning apps.

- Some comments illustrate that some learning advisors see themselves as a link, not only between students and their learning, but also between learners and their teachers, especially if they have acquired knowledge about assignments and difficult passages in the content area. Regular contacts with, and feedback to, both teachers and learners is suggested as means of accomplishing this.

- Access to a safe, secure and comfortable learning environment where students can relax and feel at ease is crucial for successful studies. Building a good rapport and being clear about the rules and the professional boundaries around the advising session creates a sense of safety and comfort for both advisors and learners.

\section{Ideas from the Academic Advisors for Appropriate Advisor Knowledge and Training}

\section{Knowledge, skills and experience}

Attendees noted that advisors need to have an eclectic mix of attributes, encompassing both knowledge and skills, such as: specific language awareness within writing and content areas; resources and source knowledge; and a good understanding of the wider supportive institutional systems and processes. Attendees also found the following important: 'learning on the job'

\section{- $\quad$ Prior life experiences}


- The understanding and skills that come with the various family roles (of mother, father, grandchild, daughter, son, sister, brother, partner, niece/nephew, etc.)

- Skills and attitudes learned and enhanced through connections and networks with a wide range different people through clubs, interests, sports, church, and traveling.

- $\quad$ Tutoring experience, which was mentioned as a particular necessity

- Knowledge about the expectations lecturers have around assessments and marking criteria as - having a student-centred approach.

Some respondents stated that current experience of being a learner, as well as a general love of learning, would also be very fruitful, especially if this was combined with advisors having previously had the experience of being an advisee. Furthermore, they thought that important skills to enable healthy and beneficial advising situations were; counselling skills, having good communication and people skills, possessing empathy along, having the ability to build relationships, being open-minded and non-judgemental, and being able to easily connect with people using emotional intelligence.

\section{Training}

The advisors in the workshop said that useful training for self-development of advisors would be peer observations of similar face-to-face advising sessions, and peer mentoring training courses which would cover many different aspects relevant to their work. Other valued ideas for self-development were: appraisals, workshops and in-service training particularly reflecting on current practice and adult literacy. They thought that clarification and up-skilling of the advising role could be further enhanced through networking at conferences, participation in e-learning MOOC courses and work situated technology courses. Such activities would also enable them to become more familiar with the online resources associated with advising. Involvement in research projects was also suggested as it would give a deeper understanding of one's own and others' advising practices and roles, and of new trends and innovations in the area. Exchanges between institutions were mentioned as very valuable e.g., a 'wananga' (publicly owned tertiary institution that provides education in a Māori cultural context) and 'non-wananga' interactive experience between institutions. 


\section{Suggestions for Good Practice from the Workshop Delegates}

This section will outline what the workshop members suggested as good practice recommendations for advising.

\section{Building relationships}

The first most important step in any advisor-student relationship was thought to be building a good working rapport with the students. This may evolve from a thorough introduction to self-studies, and a detailed orientation of the relevant premises on campus, which would help create a sense of belonging to the institution.

A specific way to foster a sense of empowerment and of belonging, within the learning family 'whanautanga' in the bicultural New Zealand framework, is to introduce or reinforce the notion of support related to the Maori educational relationship 'tuakina teina', which also involves 'korero' (conversation). As described by NZ Ministry of Education, (n.d.):

“The tuakana-teina relationship, an integral part of traditional Māori society, provides a model for buddy systems. An older or more expert tuakana (brother, sister or cousin) helps and guides a younger or less expert teina (originally a younger sibling or cousin of the same gender). In a learning environment that recognises the value of ako, the tuakana-teina roles may be reversed at any time. For example, the student who yesterday was the expert on te wā and explained the lunar calendar may need to learn from her classmate today about how manaakitanga (hospitality) is practised by the local hapū."

Some students can respond well to this nurturing and support. This can also be enhanced by Learning Facilitators (alternatively called Tutorial Assistants) being embedded into groups of learners in a learning centre. They have received some basic specific language learning \& teaching training, and are often, but not exclusively, current or recently past students themselves. They can assist learners with material and resource selection, bookings, and with technical issues relating to the hardware and software in the Centre. However, they are not highly trained in language teaching, to run advising sessions, or to deeply understand the whole process of teaching, learning and autonomy. 


\section{Metacognitive awareness}

The conference participants thought it was important that advisors facilitated the metacognitive process needed for successful learning. For example, advisors can support students learn about their preferred way of learning, assess and understand their own needs and goals, and organising their study plans and the necessary pathway for them to achieve their goals.

\section{Study skills and strategies}

The participants also mentioned that other tools such as how to access the library service and information about useful websites for guidance are important. Skills for successful studies were also discussed in the meeting/conference and they agreed that it should be introduced at an early stage, e.g., for their writing: such topics as paragraph structures, referencing, proofing, and models to compare own work with, and for reading: top-down and bottom-up techniques.

\section{Self-evaluation}

Subsequent meetings with students could then include: reflective practice, encouragement and appropriate feedback, in order to give more opportunities for extended thinking around study skills and strategies for success. These meetings could also model the methods which advisors use themselves and some of the strategies they find useful. Alternatively, advisors could give examples of what other people find useful. Another idea put forward by the workshop groups was to divide the session into three parts: (i) diagnose and recommend, (ii) give student time to work on the piece, (iii) give feedback. It was also suggested that advisors have a checklist, similar to the one suggested by Aoki (2012) which lists 14 'can do' statements under 3 broad headings: abilities, knowledge and attitudes. Aoki reported that this was particularly helpful for teachers planning to be advisors as they map out their own professional development.

It is hoped that both current and future advisors can benefit from the above wellthought-through ideas and suggestions, based on many collective years of experience. Indeed, new and experienced teachers alike, and advisors, should all be able to take and use some of the above comments and use these to the benefit of their learners (and themselves as 
advisors), as we all navigate our way through rapidly changing and increasingly digital teaching and learning environments.

\section{References}

Aoki, N. (2012). Can-do statements for advisors. In C. Ludwig \& J. Mynard (Eds.), Autonomy in language learning: Advising in action. Canterbury, UK: IATEFL.

Benson, P. (2001). Teaching and researching autonomy in language learning. Harlow, UK: Longman.

Benson, P. (2011). Teaching and researching autonomy (2nd ed). Harlow, UK: Pearson.

Benson, P., \& Voller, P. (Eds). (1997). Autonomy and independence through language learning. Harlow UK: Pearson.

Cooker, L., \& Torpey, M. (2004). From self-direction to self-access: A chronicle of learnercentred curriculum development [Special issue]. The Language Teacher: Perspectives on Self-Access, 28(6), 11-14. Retrieved from: http://jaltpublications.org/tlt/articles/704-classroom-self-access-centre-chronicle-learnercentred-curriculum-development

Crabbe, D. (1993). Fostering autonomy from within the classroom: The teacher's responsibility. System, 21(4), 443-452. doi:10.1016/0346-251X(93)90056-M

Dickinson, L., \& Wenden, A. (Eds). (1995). Introduction. Special issue on autonomy. System 23(2). doi:10.1016/0346-251x(95)90025-

Dofs, K. (2007). Helping language learners to greater independence - What works? Proceedings of the Independent Learning Association 2007 Conference. Retrieved from http://independentlearning.org/ILA/ila07/proceedings/toc

Dofs, K., \& Hobbs, M. (2011). Guidelines for maximising student use of independent learning centres: Support for ESOL learners. Christchurch \& Auckland, New Zealand: Ako Aotearoa. Retrieved from http://akoaotearoa.ac.nz/download/ng/file/group-7/guidelines-for-maximising-studentuse-of-independent-learning-centres.pdf

Gardner, D., \& Miller L. (Eds). (1994). Directions in self-access learning. Hong Kong: Hong Kong University Press.

Gardner, D., \& Miller L. (Eds). (1996). Tasks for independent language learning. Alexandria VA: TESOL

Gardner, D., \& Miller, D. (1999). Establishing self-access. Cambridge: Cambridge University Press.

Hobbs, M., \& Dofs, K. (2015). Essential advising to underpin effective language learning and teaching. Studies in Self-Access Learning Journal, 6(1), 13-31. Retrieved from 
https://sisaljournal.org/archives/mar15/hobbs_dofs/

Hobbs, M., \& J. Jones-Parry, J. (2007). In the eye of the beholder: Student perspectives of independent learning centres. In D. Gardner (Ed.), Learner autonomy 10: Integration \& support. Dublin, Ireland: Authentik.

Miller, L., \& Rogerson-Revell, P. (1993). Self-access systems. ELT Journal 47(3), 228-233. doi:10.1093/elt/47.3.228

Ministry of Education. (2014). Tertiary Education Strategy 2014-2019. Retrieved from http://www.education.govt.nz/assets/Documents/Further-education/TertiaryEducation-Strategy.pdf

Ministry of Education (n.d.). Te Reo Maori in English-medium schools. Retrieved from http://tereomaori.tki.org.nz/Curriculum-guidelines/Teaching-and-learning-te-reoMaori/Aspects-of-planning/The-concept-of-a-tuakana-teina-relationship

Mozzon-McPherson, M (2007). Supporting independent learning environments: An analysis of structures and roles of language advisors. System, 35(1), 66-92. doi:10.1016/j.system.2006.10.008

Mozzon-McPherson, M., \& Vismans, R (Eds). (2001). Beyond language teaching towards language advising. London, UK: CILT.

Mynard J., \& Carson, L. (2012). Advising in language learning: Dialogue, tools and context. Harlow, UK: Pearson.

Pemberton, R., Li, E., Or, W., \& Pierson H. (Eds). (1996). Taking control: Autonomy in language learning. Hong Kong: Hong Kong University Press.

Poulshock, J. (2010). Extensive graded reading in the liberal arts and sciences. Reading in a Foreign Language, 22(2), 304-322. Retrieved from http://nflrc.hawaii.edu/rfl/October2010/articles/poulshock.pdf

Reinders, H., Anderson, H., \& Jones-Parry, J. (2003). Self-access language learning in tertiary studies in Australia and New Zealand: a preliminary report. New Zealand Studies in Applied Linguistics 9(1), 109-114.

Reinders, H., \& Lazaro, N. (2007). Innovation in language support: The provision of technology in self-access. Computer Assisted Language Learning 20(2), 117-130. doi:10.1080/09588220701331428

Sheerin, S. (1991). Self-access: State of the art article. Language Teaching, 24(3), 143. doi:10.1017/s0261444800006315

Vinkenvleugel, I., Jones-Parry, J., \&. Lotovale, S. (2004). Which way is the right way? Is there a right way? Discovering pathways to independence. Proceedings of the Independent Learning Conference 2003, Hong Kong University of Science and Technology, HK. Retrieved from http://www.independentlearning.org/uploads/100836/ila03_vinkenvleugel_lotovale_a nd_jones-parry.pdf 